ANALES DE LA UNIVERSIDAD DE ALICANTE. HISTORIA MEDIEVAL, N. ${ }^{\circ} 16$, (2009-2010) (pp. 195-221) I.S.S.N.: 0212-2480

\title{
CIUDADES Y VILLAS DEL REINO DE ARAGÓN EN EL SIGLO XV. PROYECCIÓN INSTITUCIONAL E IDEOLOGÍA BURGUESA ${ }^{1}$
}

\author{
Germán Navarro Espinach² \\ Universidad de Zaragoza
}

\section{RESUMEN}

Once ciudades eran nombradas con este rango a finales del siglo XV en el reino de Aragón por delante de 190 villas y otras 1.213 aldeas o lugares pequeños. Esas ciudades y villas son registradas en un apéndice con sus datos institucionales esenciales: cifra de población fiscal, fechas de privilegios reales, sedes institucionales, asiento en las cortes aragonesas. El título de ciudad es estudiado en comparación con otros indicadores de promoción institucional de las villas más importantes del reino. El concepto de identidad urbana es debatido en contraste con la noción de ideología burguesa. Por último, se propone a la historiografía una lista breve de temas para el futuro próximo.

Palabras clave: Ideología burguesa, identidad urbana, rango institucional, ciudad, villa, aldea, reino de Aragón, siglo XV.

1 Doctor en Historia. Profesor Titular. Departamento de Historia Medieval, Ciencias y Técnicas Historiográficas y Estudios Árabes e Islámicos. Facultad de Filosofía y Letras. Universidad de Zaragoza. 50009. Zaragoza: C.e.: gnavarro@unizar.es.

2 El presente estudio se integra en el programa de actividades del Grupo de Investigación de Excelencia C.E.M.A. (Centro de Estudios Medievales de Aragón) del Gobierno de Aragón en el marco del proyecto interuniversitario Elites sociales y estructuras económicas comparadas en el Mediterráneo occidental (Corona de Aragón, Francia e Italia) en la Baja Edad Media, subvencionado por el Ministerio de Ciencia e Innovación durante 2009-2011 (Ref. HAR200806039). 


\begin{abstract}
Eleven cities were designed with this rank at the end of the $15^{\text {th }}$ century in the kingdom of Aragon in front of 190 towns and others 1.213 villages or small places. These cities and towns are registered in appendix with their main institutional data: tax of population, dates of royal privileges, institutional seats, presence in aragonese parliament. Status of city is studied in comparison with others pointers of institutional promotion of the most important towns of the kingdom. Concept of urban identity is discussed in contrast to the notion of bourgeois ideology. Finally, a brief list of subjects is proposed to historiography for the very near future.

Keywords: Bourgeois ideology, urban identity, institutional status, city, town, village, kingdom of Aragon, $15^{\text {th }}$ century.

\section{EL RANGO HONORÍFICO DE CIUDAD EN LA CÚSPIDE DE LA IDENTIDAD URBANA}

En el ocaso de la Edad Media había once localidades con el título de ciudad en el reino de Aragón según el fogaje general de 1495. Eran las siguientes de mayor a menor número de fuegos: Zaragoza (3.983), Calatayud (1.027), Tarazona (736), Alcañiz (702), Huesca (616), Borja (469), Barbastro (455), Daroca (437), Teruel (392), Jaca (143) y Albarracín (99). En conjunto, el territorio tenía hasta 1.424 núcleos de población distintos denominados por lo general villas, aldeas o lugares, repartidos en 47.610 kilómetros cuadrados de superficie, sumando un total de 51.056 fuegos u hogares contribuyentes ${ }^{3}$. Casi la mitad de esas unidades de poblamiento no alcanzaba los diez fuegos y el resto se situaba en su mayoría por debajo de los cincuenta. Los datos esenciales de las once ciudades en comparación con los de las 190 localidades que son denominadas villas en el citado fogaje permiten confirmar la amalgama de matices y contradicciones que existía entre el tamaño y el potencial económico de una población, la categoría jurídica y los privilegios que ostentaba, y el grado de autonomía política y proyección institucional que logró alcanzar al cabo de los años ${ }^{4}$. Para poner en evidencia los

3 SERRANO MONTALVO, A., La población de Aragón según el fogaje de 1495, 2 vols., Zaragoza, 1997, vol. II, p. LXII.

4 FALCÓN PÉREZ, M. I., «Las ciudades medievales aragonesas» en La ciudad hispánica durante los siglos XIII al XVI, Madrid, Universidad Complutense, 1985, t. II, pp. 1.159-1.200; SARASA SÁNCHEZ, E., «Concejos y ciudades medievales en el reino de Aragón. Hacia una tipología socioeconómica de los municipios aragoneses en la Edad Media: de la foralidad a la municipalidad» en Concejos y ciudades en la Edad Media Hispánica, Actas del II Congreso de Estudios Medievales de la Fundación Sánchez Albornoz, León, 1990, pp. 73-106; y SESMA MUÑOZ, J. Á., «Pequeñas ciudades y grandes villas en el ordenamiento del espacio aragonés» en Les sociétés urbaines en France méridionale et en péninsule Ibérique au Moyen Âge, París, 1991, pp. 37-50. 
diversos indicadores manejados en busca de identidades urbanas se ha elaborado como apéndice de este artículo una nómina de ciudades y villas del reino de Aragón en el siglo XV. En primer lugar se van a comentar aquellas localidades que son llamadas ciudades en el fogaje señalado con atención especial al momento y a las circunstancias en que les fue otorgado tal rango.

Zaragoza, la antigua Cesaraugusta romana fundada en el siglo I antes de nuestra era, fue epicentro regional también durante las centurias posteriores en tiempos de visigodos y musulmanes. Tras la conquista cristiana en 1118, el rey Alfonso I le otorgó fueros con la categoría jurídica implícita de ciudad, corroborada al restaurarse la sede episcopal que más adelante, en 1318, se elevaría a arzobispado. El tamaño de la población creció mucho desde 1369 (2.480 fuegos) o 1405 (2.864) hasta alcanzar los 3.983 fuegos durante los años 1472-14965. Con esa cifra por aquel entonces Zaragoza era la mitad que Valencia (8.840 en 1489), un tercio menos que Barcelona (5.749 en 1497) o el doble que Mallorca (2.055 en 1444) ${ }^{6}$. Fue además cabeza de merinado, sobrecollida y sobrejuntería. Con su asiento en las cortes aragonesas presidía siempre el brazo o estamento de las universidades, llegando a acoger catorce reuniones del parlamento del reino desde 1365-1367 a 1498. La historia institucional del concejo de Zaragoza en el siglo XV se conoce bien a partir de la tesis doctoral de María Isabel Falcón ${ }^{7}$, ampliada en los últimos años por nuevos estudios sobre las elites locales ${ }^{8}$.

5 Zaragoza tenía 3.983 fuegos en 1496 según Serrano o 3.969 según FALCÓN PÉREZ, M. I., «Aportación al estudio de la población aragonesa a finales del siglo XV» en Aragón en la Edad Media, V (1983), pp. 255-302 (véase el índice alfabético de lugares y fuegos). Los fuegos de principios de siglo en SESMA MUÑOZ, J. Á., ABELLA SAMITIER, J., «La población del reino de Aragón según el fogaje de 1405» en J. Á. Sesma Muñoz y C. Laliena Corbera (coordinadores), La población de Aragón en la Edad Media (siglos XIII-XV). Estudios de demografía histórica, Zaragoza, 2004, pp. 115-163. La edición de dicho fogaje se ha realizado en el vol. 2 de NAVARRO ESPINACH, G. (ed.), Cortes del reinado de Martín I, Acta Curiarum Regni Aragonum, t. VI, 2 vols., Zaragoza, 2008.

6 SESMA MUÑOZ, J. A., «La población urbana en la Corona de Aragón (siglos XIV-XV)»e IRADIEL MURUGARREN, P. «Metrópolis y hombres de negocios (siglos XIV y XV)» en Las sociedad urbanas en la España medieval, XXIX Semana de Estudios Medievales de Estella, Pamplona, 2003, pp. 151-193 y 277-310 respectivamente.

7 FALCÓN PÉREZ, M. I., Organización municipal de Zaragoza en el siglo XV, Universidad de Zaragoza, 1978. Véase también de la citada autora sus dos libros Zaragoza en el siglo XV. Morfología urbana, huertas y término municipal, Zaragoza, Institución Fernando el Católico, 1981; y El municipio de Zaragoza entre 1468 y 1472 según los Libros de Actos Comunes de sus Jurados, Ayuntamiento de Zaragoza, 2006.

8 BARRAQUÉ, J. P., Saragosse à la fin du Moyen Age. Una ville sous influence, París, LHarmattan, 1998; MAINE BURGUETE, E., Ciudadanos honrados de Zaragoza. La oligarquía zaragozana en la Baja Edad Media (1370-1410), Universidad de Zaragoza, 2006; LOZANO GRACIA, S., Las elites de la ciudad de Zaragoza a mediados del siglo XV. La aplicación del método prosopográfico en el estudio de la sociedad, Tesis Doctoral, Universidad de Zaragoza, 2008. 
Al igual que Zaragoza, tanto Jaca como Huesca, Barbastro y Tarazona recibieron también el título de ciudad desde la conquista cristiana. La población que ostentaba la concesión más antigua del reino fue Jaca, la primera residencia regia a la vez que sede del obispado de Aragón desde 1042. El rey Sancho Ramírez le otorgó fuero en 1077, convirtiéndola en ciudad. Después recibió privilegios para la celebración de feria (1187) y mercado (1197), actuando como merinado y lugartenencia de sobrejuntería, con asiento en cortes ${ }^{9}$. Barbastro recibió tras su conquista por Pedro I en 1100 un fuero de infanzones y la categoría de ciu$\mathrm{dad}^{10}$. Tarazona fue en origen una población celtíbera y romana que tuvo iglesia episcopal en época visigoda. En 1119, una vez conquistada por los cristianos, recibió los fueros de Zaragoza con la categoría de ciudad y se restauró la antigua sede eclesiástica ${ }^{11}$.

Por su parte, Huesca fue una medina islámica conquistada por Pedro I en 1096. Cuatro años después el rey le otorgó privilegios y franquicias y se trasladó allí la sede episcopal de Jaca, pasando a tener desde entonces la consideración de ciudad. El monedaje oscense de 1284 censa 1.341 contribuyentes cristianos $^{12}$ aparte de las aljamas de mudéjares y judíos. Sin embargo, en el siglo XV la población se redujo a 755 fuegos en 1405 y 616 en 1495 . Huesca fue merinado y lugartenencia de sobrejuntería. Tuvo asiento en cortes y acogió una reunión del parlamento aragonés en 1247. El concejo medieval ha sido estudiado en la tesis doctoral de María Teresa Iranzo ${ }^{13}$, analizando no sólo la historia de la institución y sus finanzas, sino también las estrategias de promoción y las trayectorias familiares de clase de los grupos dirigentes locales que estuvieron implicados en el gobierno de dicha ciudad.

Las otras poblaciones aragonesas que recibieron el rango de ciudad no lo tuvieron desde la conquista sino a partir del año 1300 en adelante. Me refiero a Albarracín, Calatayud, Daroca, Teruel y Borja, porque el caso de la villa de Alcañiz, que aparece como ciudad en el fogaje de 1495, se comentará al final en relación

9 FALCÓN PÉREZ, M. I., «Trayectoria medieval de Jaca en el seno de la Corona de Aragón» en XV Congreso de Historia de la Corona de Aragón, Zaragoza, 1994, t. III, pp. 15-76.

10 SESMA MUÑOZ, J. A., LALIENA CORBERA, C., "La población de Barbastro y sus estrategias políticas y económicas a mediados del siglo XV» en Revista d'Història Medieval, 10 (1999), pp. 123-160.

${ }^{11}$ CORRAL LAFUENTE, J. L., «Tarazona y sus términos en los siglos XV y XVI: Derechos y privilegios» en Tvriaso, 4 (1983), pp. 111-153.

12 UTRILLA UTRILLA, J. F., «El monedaje de Huesca de 1284. Contribución al estudio de la ciudad y sus habitantes» en Aragón en la Edad Media, I (1977), pp. 1-50.

${ }^{13}$ IRANZO MUÑÍO, M. T., Elites políticas y gobierno urbano en Huesca en la Edad Media, Ayuntamiento de Huesca, 2005. Véase también de la misma autora Política municipal y vida pública en Huesca. Documentos (1260-1527), Zaragoza, 2008. 
con otros ejemplos similares de identidad ambigua de ciudad/villa. Respecto a Albarracín, capital de taifa musulmana, desde su conquista cristiana en 1170 fue una villa de señorío en manos de los Azagra y los Lara. En 1172 se creó en la villa el obispado de Santa María, dependiente de la sede toledana. El señorío no quedó incorporado a Aragón hasta que Pedro III lo reconquistara en 1284. Fue tras la anexión cuando el propio rey creó la comunidad de aldeas. Y tras unos años conflictivos, en 1300 Jaime II arrebató a los Lara la villa y el término y los incorporó al realengo otorgándole el título de ciudad ${ }^{14}$.

Calatayud en su origen fue una antigua fortaleza musulmana a cuatro kilómetros y medio al sudeste de la Bílbilis romana. Conquistada asimismo por Alfonso I en 1120, años después recibió un fuero de extremadura con muchas exenciones fiscales y un amplio alfoz de aldeas (1131). Éstas se institucionalizaron en comunidad en 1254 por privilegio de Jaime $I^{15}$. En esa última fecha ya se registraban hasta 1.271 contribuyentes cristianos en la que todavía era considerada como villa, a los que cabría añadir una cifra indeterminada de judíos y mudéjares ${ }^{16}$. Durante el mismo siglo XIII obtuvo privilegios para celebrar feria (1276) y mercado (1286), pero el título de ciudad no llegó hasta que Pedro IV se lo concedió en las cortes aragonesas de 1365-1366. En verdad, tuvo que esperar a 1391 para que Juan I extendiera el privilegio correspondiente.

El texto de las actas de las cortes donde figura la concesión del título de ciudad a la villa de Calatayud muestra cómo el propio Pedro IV quiso agradecerles a sus habitantes la defensa del reino que hicieron contra las tropas castellanas en plena guerra de los Dos Pedros, siendo por ello dignos de gran honra y merecimiento: Por esto, queriendo aquellos ennoblescer et gualardonar del buen servicio que feyto le havian, constituye et creho la dita villa de Calatayu en et por ciudat, assi que d'aqui adelant ciudat se nompnasse et de todos los otros ciudat fuesse clamada. Et los procuradores de la dita ciudat de Calatayu et de sus aldeas et todos los otros de ciudades, villas et villeros del dito regno agradescieron muyto al senyor rey con besamiento de manos la gracia et merce que feyto havia a

${ }^{14}$ BERGES SÁNCHEZ, J. M., «El intervencionismo de la monarquía en el régimen municipal de Albarracín según las Ordinaciones de 1438» en Jornadas de Estudio sobre los Fueros de Teruel y Albarracín, Teruel, 2000, pp. 209-225; y del mismo autor, «La comunidad de Albarracín: orígenes y evolución durante la Baja Edad Media» en J. M. Latorre Ciria (coord.), Estudios Históricos sobre la Comunidad de Albarracín, Teruel, 2003, vol. 1, pp. 63-199.

${ }^{15}$ CORRAL LAFUENTE, J. L., «La génesis de la comunidad de Calatayud» en Aragón en la Edad Media, XVI (2000), Homenaje al profesor emérito Ángel San Vicente Pino, pp, 197-214.

${ }^{16}$ UTRILLA UTRILLA, J. F., «La población de Calatayud y su comunidad de aldeas ante la crisis demográfica del siglo XIV (1350-1414)» en J. Á. Sesma Muñoz y C. Laliena Corbera (coordinadores), La población de Aragón en la Edad Media (siglos XIII-XV). Estudios de demografía histórica, Zaragoza, 2004, pp. 403-467. 
los de la dita ciudat de Calatayu ${ }^{17}$. La nueva ciudad registró en el fogaje general de 1405 una cifra de 1.295 contribuyentes que en 1495 se había reducido a 1.027. Fue sede de merinado y sobrecollida y tuvo asiento en cortes, celebrándose allí reuniones del parlamento aragonés en los años 1365-1366, 1411, 1461 y 1515. Están editadas unas ordenanzas municipales de Calatayud que datan de 1423 a partir de las cuales se ha realizado una primera aproximación a la clase dirigente ${ }^{18}$.

Daroca, de origen musulmán, fue conquistada por Alfonso I a la vez que Calatayud como consecuencia de la batalla de Cutanda de 1120. Su fuero de extremadura lo obtuvo en 1142 por concesión de Ramón Berenguer IV ${ }^{19}$. Aparte de los colectivos de judíos y mudéjares, en 1230 tenía 926 contribuyentes cristianos ${ }^{20}$. La comunidad de aldeas quedó constituída formalmente en 1248 por concesión de Jaime I ${ }^{21}$. En 1294 recibió otro privilegio para la celebración de feria. Su historia volvió a correr paralela a la de Calatayud cuando en las mismas cortes de 1365-1366 se le otorgó a la vez el título de ciudad por razones similares según se lee en las actas del citado parlamento: Assimismo, el dito senyor rey reconto en plena cort el servicio que los de la villa de Darocha le havian feyto, los quales havian seydo muro deffensible de los enemigos a todo el regno, por la qual razon eran meritorios de haver nobleza et todo bien. Por aquesto, queriendo aquellos ennoblescer, creho et fizo la dita villa de Darocha en et por ciudat, assi que de aqui adelant ciudat se nopnasse et por todos los otros ciudat fuese nompnada et clamada ${ }^{22}$. La documentación medieval de esta nueva ciudad de Daroca ha sido estudiada en la tesis doctoral de María Luz Rodrigo ${ }^{23}$.

${ }^{17}$ LAliEnA CORBERA, C. (ed.), Cortes del reinado de Pedro IV/2, Acta Curiarum Regni Aragonum, t. III, Zaragoza, 2008, p. 87.

${ }^{18}$ GALINDO ANTÓN, J., Ordenanzas municipales de la ciudad de Calatayud. Año MCDXXIII, Zaragoza, Centro de Estudios Bilbilitanos, 1996; e IRANZO MUÑíO, M. T., «Estrategias de clase y gobierno urbano: Las Ordenanzas de Calatayud de 1423» en Aragón en la Edad Media, XII (1995), pp. 183-200.

${ }^{19}$ AGUDO ROMEO, M. M., El fuero de Daroca. Introducción, edición crítica, traducción, estudio léxico y concordancia, Daroca, Centro de Estudios Darocenses, 1992.

${ }^{20}$ CORRAL LAFUENTE, J. L., «La población de Daroca según un listado parroquial de 1230» en J. A. Sesma Muñoz y C. Laliena Corbera (coordinadores), La población de Aragón en la Edad Media (siglos XIII-XV). Estudios de demografía histórica, Zaragoza, 2004, pp. 195-221.

${ }^{21}$ CORRAL LAFUENTE, J. L., La comunidad de aldeas de Daroca en los siglos XIII y XIV: Origen y proceso de consolidación, Zaragoza, Institución Fernando el Católico, 1987.

${ }_{22}^{2}$ LALIENA (ed.), Cortes del reinado de Pedro IV/2, citado, p. 87.

${ }^{23}$ RODRIGO ESTEVAN, M. L., Poder y vida cotidiana en una ciudad bajomedieval: Daroca (14001526), Tesis Doctoral, Universidad de Zaragoza, 1996. Véase de la misma autora La ciudad de Daroca a fines de la Edad Media. Selección documental (1328-1526), Daroca, Centro de Estudios Darocenses, 1999. 
La villa de Teruel, una aldea musulmana, fue conquistada en 1169 por Alfonso II y recibió fuero de extremadura en $1177^{24}$. En 1248 aparece el término de comunidad de aldeas, aunque la definitiva segregación entre las aldeas y el concejo data del año $1277^{25}$. En el siglo XIII obtuvo privilegios de mercado (1208 y 1259) y feria (1277). Por la lealtad demostrada a la corona en la lucha contra los de la Unión aragonesa ${ }^{26}$, Pedro IV no sólo concedió a la citada villa de Teruel el privilegio de ciudad en las cortes de 1347, sino que también intentó elevar su iglesia a la categoría de catedral, para lo cual envió a Roma un nuncio especial: Tractabimus pro posse cum domino sumo pontifice, cui proinde certum et solemnem nuntium seu legatum intendimus destinare, quod ipse ordinet in civitate ipsa sedem et ecclesiam cathedralem, providendo inibi de episcopo, qui episcopatum habeat sub certis limitationibus terminatum dotatumque certis redditibus, prout dictus dominus sumus pontifex ordinaverit faciendum ${ }^{27}$. La propuesta al papa no surtió efecto. Tiempo después, en 1423 la iglesia de Teruel obtuvo el título de colegiata con un cabildo de diez canónigos y varios beneficiados, pero no fue sede episcopal hasta época de Felipe II. El estudio del concejo de Teruel hasta 1327 fue llevado a cabo por Antonio Gargallo ${ }^{28}$, y ha sido completado posteriormente con otros trabajos sobre las elites locales en el siglo $X^{29}$.

En cuanto a Borja se sabe que fue conquistada por Alfonso I entre 1119 y 1124 y tuvo su fuero propio ${ }^{30}$. Durante toda la época medieval fue villa de señorío con un colectivo importante de infanzones entre su vecindario. El 2 de octubre de 1438 el rey Alfonso V la incorporó al realengo y le otorgó el rango

${ }^{24}$ CASTAÑÉ LLINÁS, J. L., El fuero de Teruel, Ayuntamiento de Teruel, 1991.

${ }^{25}$ GARGALlO MOYA, A., Los orígenes de la comunidad de Teruel, Teruel, Instituto de Estudios Turolenses, 1984.

${ }^{26}$ LALIENA CORBERA, C., «La adhesión de las ciudades a la Unión: poder real y conflictividad social en Aragón a fines del siglo XIII» en Aragón en la Edad Media, VIII (1988), Homenaje al profesor emérito Antonio Ubieto Arteta, pp. 399-413.

${ }^{27}$ El privilegio de ciudad para Teruel fue publicado por BLASCO DE LANUZA, V., Historias eclesiásticas y seculares de Aragón, Zaragoza, 1622, pp. 279-280.

${ }^{28}$ GARGAllO MOYA, A., El concejo de Teruel en la Edad Media, 1177-1327, 4 vols., Teruel, Instituto de Estudios Turolenses, 1997-2005.

${ }^{29}$ NAVARRO ESPINACH, G., «Muñoces, Marcillas y otras familias dominantes en la ciudad de Teruel (1435-1500)» en Anuario de Estudios Medievales, 32/1 (2002), pp. 723-775. Véase también del mismo autor «El Hospital de Santa María de Villaespesa y de San Juan Bautista en la ciudad de Teruel a través de los actos notariales de Alfonso Jiménez (1481-1518)» en Aragón en la Edad Media, XVI (2000), Homenaje al profesor emérito Ángel San Vicente Pino, pp. 565-590; y NAVARRO ESPINACH, G., VILLANUEVA MORTE, C., «Gil Sánchez Muñoz (1370-1447), el antipapa Clemente VIII. Documentación inédita de los archivos de Teruel» en Anales de la Universidad de Alicante. Historia Medieval, 15 (2006-2008), pp. 239-254.

${ }^{30}$ MORALES, J. J., PEDRAZA, M., Fueros de Borja y Zaragoza, Zaragoza, Editorial Anubar, 1986. 
jurídico de ciudad por los numerosos servicios prestados en la defensa de la frontera del reino. En verdad, fue del concejo de Borja del que partió la iniciativa para que se le concediera con vistas a que sus habitantes adquiriesen la condición de ciudadanos con las prerrogativas, honores y exenciones que tenían los que vivían en las ciudades del reino, además de solicitar que se construyese allí una catedral que fuera sede de un obispo. Pero después el monarca no sólo vendió la población a un noble para conseguir dinero sino que además olvidó su título y la siguió llamando villa. Y no fue hasta el 16 de julio de 1443 cuando la propia reina doña María, nueva señora de la villa, confirmó el título de ciudad para Borja definitivamente, aunque fracasó el intento de crear un obispado ${ }^{31}$.

En contraste, el caso de la villa de Alcañiz, denominada ciudad en el fogaje aragonés de 1495, siembra la duda. En ningún lado consta que se produjera la concesión de tal categoría para esta villa de señorío ${ }^{32}$. Está claro que era la cuarta población del reino en 1495 con 702 fuegos. Tenía sus propias aldeas y era encomienda de la orden de Calatrava, además de sobrecollida y lugartenencia de sobrejuntería. Tuvo asiento en cortes y acogió la famosa reunión del parlamento aragonés de 1411 que preparó el Compromiso de Caspe. En una situación similar estuvo también Monzón, a la que el rey Sancho Ramírez concedió el título de ciudad en 1089 pero siempre figuró como villa. Fue una población importante, de hecho, en 1293 se contabilizaron 684 varones cristianos mayores de catorce años en su vecindario cuando prestaron juramento como vasallos de la orden del Temple $e^{33}$. Se le concedió privilegio de feria en 1311. En el fogaje de 1495 tenía 314 fuegos y figura como villa de señorío y encomienda de la orden del Hospital. Fue además la sede habitual de las reuniones de las cortes generales de la Corona de Aragón desde 1362-1363 a 1512-1514.

Con Tamarite de Litera ocurre algo parecido a Alcañiz y Monzón. Era una villa de realengo que junto con sus propias aldeas alcanzaba los 227 fuegos en 1495. Fue sede de merinado y lugartenencia de sobrejuntería, además de tener asiento en cortes y albergar una reunión de las mismas en 1375. La conquistó Alfonso I en 1107 y recibió en 1169 los fueros de Zaragoza. Cuando Pedro IV confirmó dichos fueros a la población en 1337 declaró infanzones a los vecinos y dispuso que la villa fuera ciudad, rango que fue confirmado por Martín I en 1408, pero siempre figuró como villa ${ }^{34}$.

${ }^{31}$ FALCÓN PÉREZ, M. I., «La localidad aragonesa de Borja: su azaroso tránsito de villa a ciudad» en Acta Medievalia. Homenaje a la doctora Carmen Batlle, Barcelona, 2005, pp. 205-219.

32 VIDIELLA JASA, S., «Desarrollo del municipio de Alcañiz después de la reconquista» en Boletín de Historia y Geografía del Bajo Aragón, I (1907), pp. 5-20, 45-59 y 97-114.

33 SESMA MUÑOZ, J. Á., «Demografía y sociedad: la población de Monzón en los siglos XIIIXV» en Homenaje a José María Lacarra, Pamplona, 1986, vol. II, pp. 687-710.

${ }^{34}$ El caso de Tamarite de Litera como el de Monzón fueron tratados en su día por FALCÓN, «Las ciudades medievales aragonesas», citado, p. 1.161. 


\section{LAS ALDEAS QUE SON COMO VILLAS Y LAS VILLAS QUE SON COMO CIUDADES}

Estos problemas de identidad urbana en las poblaciones del reino de Aragón durante la Edad Media se manifiestan en varios ejemplos más. En las cortes de 1413-1414 los procuradores de la ciudad de Teruel protestaron contra las pretensiones de los de Mosqueruela que querían considerarse villa siendo como eran una aldea de la comunidad turolense: Muyt alto princep et muyt poderoso senyor. Delant la vuestra presencia et en la cort del regno de Aragon perecen los vuestros humiles sindicos Pero Martinez de Marziella et Johan Munyoz, subditos et procuradores de los officiales et hombres de la universidat de la ciudat de Teruel, Pero Gil de Palomar et Gil Dominguez, savios en dreyto, sindicos et procuradores de la comunidat de las aldeas de la antedita ciudat et de la villa de Mosqueruela. Et humilment supplicantes dizen que, atendientes et considerantes que yes question siquiere altercacion entre la universidat de la antedita ciudat de la una part et la comunidat de las aldeas et la villa de Mosqueruela de la otra, sobre esto que la part de la universidat de la antedita ciudat dize et affirma que [f. 142v] a actos de cortes deven seyer constituidos procuradores o sindicos por las ditas ciudat et aldeas, includiendo soz las ditas aldeas Mosqueruela et no pas distintament asi como agora yes feyto por las ditas aldeas et Mosqueruela. Et que Mosqueruela yes et deve seyer havida por aldea et compresa soz las ditas aldeas et no deve seyer villa ni dever por tal seyer havida o reputada, los procuradores et comunidat de las ditas aldeas et villa de Mosqueruela de per si et distintament et menos de la ciudat ha podido et podia constituyr procuradores et sindicos pora los actos de cortes de Aragon, et que Mosqueruela yes et deve seyer havida villa et por villa et es de la dita comunidat et del cuerpo de aquella. Et que estas alteraciones buenament agora decidir no se podrian et que por ventura los actos de la dita cort ne podrian prender embargo o turbacion. Por esto los ditos procuradores et sindicos quirieron et quieren, et en pacto deduzieron et deduzen que por la compericion que han feyto, fazen et faran en la present cort, et por los actos que en aquella se subsiguiran o son feytos no sia engenrado prejudicio alguno a las ditas partes ni ad alguna dellas en possession ni en propriedat sobre los dreytos que a las ditas partes et a qualquiere dellas pertenecen o pertenecer deven en et sobre las anteditas cosas, antes las ditas partes et qualquiere dellas finquen en su dreyto et que no pueda seyer sacado a cosenquencia en lo advenidero. Et supplican, senyor, que ad aquesto vuestra senyoria devye prestar actoridat et consentimiento, et encara la antedita cort consintimiento ${ }^{35}$.

En efecto, Mosqueruela, a pesar de ser una aldea de la comunidad de Teruel, figura de hecho en el fogaje de 1495 como villa de realengo de dicha comunidad

\footnotetext{
${ }^{35}$ NAVARRO ESPINACH, G. (ed.), Cortes del reinado de Fernando I, Acta Curiarum Regni Aragonum, t. VIII, Zaragoza, 2009, pp. 332-333.
} 
con 89 fuegos. Recuérdese que recibió privilegios de mercado y feria en 1366. Su caso era como el de Rubielos, otra aldea de Teruel que era denominada villa y tenía privilegios de feria y mercado. Más aún, Rubielos tuvo sus propias ordenanzas municipales y ejerció dominio sobre algunos lugares de su entorno como Nogueruelas o Fuentes, a modo de diminuta comunidad de aldeas propia, hasta el punto de que Alfonso V otorgó a esta población jurisdicción exclusiva sobre esos dos lugares, lo que ocasionó pleitos continuados con la ciudad de Teruel ${ }^{36}$. Situación perfectamente comprensible si se explica en el contexto general de la lucha política de aldeas contra villas en el reino ${ }^{37}$.

Los casos de las villas de Mosqueruela y Rubielos en la comunidad de aldeas de Teruel debieron ser parecidos a los de Aguilón, Cariñena, Huesa, Monreal, Plenas o Segura, villas de la comunidad de aldeas de Daroca, o a los de Ibdes y Villarroya, villas de la comunidad de aldeas de Calatayud. También es digno de consideración el ejemplo de aquellas villas que, sin tener una comunidad de aldeas institucionalizada a la manera de Calatayud, Daroca, Teruel o Albarracín ${ }^{38}$, mantuvieron un grupo de lugares dependientes de ellas, tal y como confirma su propia historia o el mismo fogaje de 1495: Alcañiz, Almudévar, Alquézar, Fraga ${ }^{39}$, Montalbán ${ }^{40}$, Murillo, Sariñena o Tamarite de Litera. Sin olvidar que existieron organizaciones comunales o mancomunidades de pueblos de algunas encomiendas que, como si se tratase de las citadas comunidades de aldeas del sur de Aragón, celebraban sus plegas no sólo entre ellos sino también con representantes de las villas de las otras encomiendas vecinas, tal y como se ha podido conocer recientemente a través del libro de la bailía de Cantavieja respecto a las asambleas sin presencia de autoridad señorial que se celebraban regularmente entre las poblaciones de esa encomienda junto con las de Aliaga y Castellote, habiendo intentado incluso establecer una hermandad general de villas de la orden del Hospital con las encomiendas de Caspe y Monzón ${ }^{41}$.

Por otro lado, las villas que tuvieron asiento en las cortes aragonesas manifestaban de esa manera una proyección institucional de primer nivel a pesar de no tener rango

${ }^{36}$ NAVARRO ESPINACH, G., MUÑOZ GARRIDO, V., APARICI MARTí, J., ABAD ASENSIO, J. M., Rubielos de Mora en la Edad Media, Teruel, Instituto de Estudios Turolenses, 2005.

${ }^{37}$ CORRAL LAFUENTE, J. L., «Aldeas contra villas: señoríos y comunidades en Aragón (siglos XII-XV)» en Señorío y feudalismo en la Península Ibérica (ss. XII-XIX), Zaragoza, Institución Fernando el Católico, 1993, vol. 1, pp. 487-499.

38 CORRAL LAFUENTE, J. L., «El origen de las comunidades medievales aragonesas» en Aragón en la Edad Media, VI (1984), pp. 219-254.

${ }^{39}$ REDONDO VEINTEMILLAS, G., Libro de privilegios de Fraga y sus aldeas, 2 vols., Zaragoza, Cortes de Aragón, 1999.

${ }^{40}$ AGUDO ROMEO, M. M., LAPEÑA PAÚL, A. I., El Fuero de Montalbán. Estudio y transcripción, Ayuntamiento de Montalbán, 2000.

${ }^{41}$ NAVARRO ESPINACH, G., VILLANUEVA MORTE, C., Libro de la bailía de Cantavieja (14281470), Zaragoza, 2009. 
de ciudad: Aínsa42 Alagón $^{43}$, Alcañiz, Almudévar, Alquézar, Ejeaa, Fraga, Magallón, Montalbán, Monzón, Ricla, Sádaba, San Esteban de Litera, Sariñena, Sos ${ }^{45}$, Tamarite de Litera, Tauste y Uncastillo. Sin embargo, también es cierto que otras muchas villas tuvieron entidad para estar y no fueron nunca convocadas, aunque se hicieron presentes a través de la formulación de greuges, como las propias villas de las bailías de Aliaga, Cantavieja y Castellote antes citadas. Sin lugar a dudas, la gran mayoría de las villas de señorío tenían una entidad demográfica importante pero estuvieron limitadas en su proyección institucional en comparación con las poblaciones de realengo convocadas a cortes. Entre las más destacadas villas señoriales que cabe citar por su nivel de población en el fogaje de 1495 están Caspe (295 fuegos), Villafeliche (261), Belchite (245), Albalate del Arzobispo (238), Aranda (207), Fuentes (197), Maella (196), Cetina (186), La Almunia (185), La Fresneda (180), Alcorisa (176), Molinos (166), Mora (158), Pina (157) y Mallén (156). Como puede comprobarse, todas estas villas eran más grandes que las ciudades de Jaca o Albarracín por las mismas fechas.

En los últimos años algunas villas aragonesas de señorío empiezan a tener estudios propios que desvelan la actividad de sus concejos. Es el caso de ciertas localidades del área fronteriza con el reino de Valencia como Puertomingalvo ${ }^{46}$, Mirambel $^{47}$, Villarluengo ${ }^{48}$ o Las Cuevas de Cañart ${ }^{49}$. Son todos estudios posteriores al año 2000, fecha en la que se publicó un balance detallado sobre las investigaciones realizadas acerca de las ciudades y villas aragonesas de la Edad

42 Sobre la villa de Aínsa véase UTRILla UTRILLA, J. F., NAVARRO ESPINACH, G., «Conflictividad social y luchas de bandos en los valles pirenaicos del Sobrarbe y la Ribagorza hacia 1400» en J. P. Barraqué y Ph. Sénac (eds.), Habitats et peuplement dans les Pyrénées au Moyen Âge et à l'èpoque moderne, Toulouse, 2009, pp. 183-194.

${ }^{43}$ PÉREZ VIÑUALES, M. P., Alagón en la Baja Edad Media (1400-1450), Zaragoza, Institución Fernando el Católico, 2005.

${ }^{44}$ LAPEÑA PAÚl, A. I., AGUDO ROMEO, M. M., El fuero de Ejea de los Caballeros y su difusión, Zaragoza, Diputación de Zaragoza y El Justicia de Aragón, 2003. Véase también PIEDRAFITA PÉREZ, E., Las Cinco Villas en la Edad Media, Zaragoza, Institución Fernando el Católico, 2005.

${ }^{45}$ ABELLA SAMITIER, J., La villa aragonesa de Sos en la Baja Edad Media: economía, sociedad y manifestaciones del poder, Tesis Doctoral, Universidad de Zaragoza, 2007. Véase del mismo autor Selección de documentos de la villa aragonesa de Sos (1202-1533), Zaragoza, Institución Fernando el Católico, 2009.

${ }^{46}$ MEDRANO ADÁN, J., Puertomingalvo en el siglo XV. Iniciativas campesinas y sistema social en la montaña turolense, Teruel, Instituto de Estudios Turolenses, 2006.

${ }^{47}$ NAVARRO ESPINACH, G., Cuentas del concejo de Mirambel (1472-1489), Zaragoza, 2008.

${ }^{48}$ NAVARRO ESPINACH, G., APARICI MARTí, J., «Villarluengo, un lugar de la bailía de Cantavieja en el siglo XV» en Aragón en la Edad Media, XX (2008), Homenaje a la profesora María Desamparados Cabanes Pecourt, pp. 543-558.

${ }^{49}$ PALlARÉS JIMÉNEZ, M. Á., Las Cuevas de Cañart a finales de la Edad Media según la documentación notarial de Bernardo Fulla (1443-1509), Las Cuevas de Cañart, Asociación Cultural El Morrón, 2006. 
Media a cargo de María Isabel Falcón ${ }^{50}$. Lo que debe quedar claro a estas alturas es que rastrear formas de identidad urbana sólo en la documentación conservada por las ciudades o poblaciones más grandes y prósperas de un territorio puede dejar de lado datos valiosos procedentes de villas o incluso aldeas que imitaban o expresaban paralelamente idearios políticos afines a los de dichas localidades principales. Entre otras cosas porque hubo lugares cuyo tamaño y riqueza fue igual o mayor que el de alguna ciudad que ostentó dicho título simbólico por privilegio real. Y tampoco estaban todas las que podrían haber estado atendiendo a su fuerza económica y social en la nómina de poblaciones que eran convocadas a cortes para constituir el estamento de las universidades del reino. En ese sentido, el mundo de las comunidades de aldeas es digno de análisis, sobre todo porque algunas de ellas no sólo tuvieron una función relevante en su territorio inmediato sino que llegaron a reivindicarse como villas independientes. Y es que una cosa es lo que los prohombres de los concejos quisieran que fuesen sus localidades, la identidad de ciudad o villa que aspiraban tener, y otra cosa muy distinta es lo que la monarquía o las otras poblaciones del reino les permitieron atribuirse.

Habrá que quedarse pues con la definición esencial de identidad urbana que existió en la propia Edad Media. Las palabras burguesía o burgués fueron utilizadas en la documentación europea desde el siglo XII para referirse a los ciudadanos honrados y privilegiados de una ciudad. En efecto, el fuero de Jaca de 1077 ya clasificaba a los pobladores francos de dicha ciudad entre caballeros, burgueses y rústicos: miles vel burgensis aut rusticus ${ }^{51}$. Desde entonces, el burgués quedó definido sobre todo por su libertad dentro del mundo feudal, con las franquicias específicas que conllevaba en el ámbito urbano, a la vez que por la naturaleza peculiar de su actividad económica, centrada en la industria, el comercio o el ejercicio de una profesión liberal.

En el reino de Aragón así lo entendía en el siglo XIII el obispo Vidal de Canellas, quien definió a los burgueses como aquellos que vivían en ciudades o en villas que eran como ciudades, y cuyo medio de vida consistía en la explotación de una industria con operarios, en el comercio al por mayor, en el ejercicio bancario (cambistas), o en alguna actividad profesional (juristas, notarios, médicos y otros

50 FALCÓN PÉREZ, M. I., «Las ciudades medievales aragonesas» en La ciudad hispánica durante los siglos XIII al XVI, Madrid, Universidad Complutense, 1985, vol. II, pp. 1.1591.200; e «Historia de las ciudades y villas del reino de Aragón en la Edad Media. Evolución y desarrollo de los estudios en los últimos veinticinco años» en En la España Medieval, 23 (2000), pp. 395-439.

${ }^{51}$ LEDESMA RUBIO, M. L., Cartas de población del Reino de Aragón en los siglos medievales, Zaragoza, Institución Fernando el Católico, 1991, doc. 2, p. 27. Véase asimismo MOLHO, M., El fuero de Jaca, nueva reedición crítica en 2 vols., Zaragoza, El Justicia de Aragón, 2003. 
similares): Cipdadanos son todos aqueillos qui moran en las cipdades o en las villas que son como cipdades, de los quoales logares aqueillos son ditos burgeses los quoales, maguer ayan cabdaleros et servientes por los quoales trayen los sus officios, empero no usan eillos por sus manos aqueillos officios, empero son unos officios que, maguer por sus manos usen, no son itados de la orden de los burgeses, assí como son aqueillos qui venden los paynnos de precio et camiadores et sobre todo esto vozería o física o çirurgía et otras cosas igoales déstas ho mayores ${ }^{52}$. Recuérdese que ese siglo XIII fue sin duda el de mayor expansión demográfica en toda Europa, de hecho Aragón nunca tuvo en la Edad Media tanta población como entonces ${ }^{53}$. No se olvide tampoco que si la identidad urbana estuvo presente en villas que eran como ciudades según el obispo, también lo debió estar en las aldeas que eran como villas.

\section{3. ¿IDENTIDADES URBANAS O FORMAS DE IDEOLOGÍA BURGUESA?}

Llegados a este punto de la exposición, parece conveniente discutir sobre la pertinencia o no del concepto de identidades urbanas. En primer lugar, porque como afirma José Ángel García de Cortázar ${ }^{54}$ al menos en España el oficio de historiador no suele incluir al de historiógrafo con la subsiguiente falta de reflexión previa que ello supone acerca de los temas que se investigan, la metodología aplicada, las interpretaciones al uso o los objetivos que se persiguen ${ }^{55}$. Y en segundo lugar porque en los últimos años, como él mismo dice, está tomando protagonismo una nueva historia cultural que se interesa menos por recuperar la experiencia de las personas en el pasado y más por analizar las imágenes de identidad y alteridad que las representaron. El resultado es que no sólo han pasado de moda los análisis sobre la organización social del espacio, la historia económica o la historia social en general, sino que ahora además se arrinconan las nociones de clase, estamento o ideología a cambio de defi-

52 CABAnes PeCourt, M. D., Blasco Fernández, A., PUeyo COlOMinA, P., Vidal Mayor. Edición, introducción y notas al manuscrito, Zaragoza, Libros Certeza, 1997, p. 247.

53 SESMA MUÑOZ, J. Á., «Las ciudades de Aragón y Cataluña interior: población y flujos económicos (1150-1350)» en Le città del Mediterraneo all'Apogeo dello sviluppo Medievale: Aspetti economici e sociali, Atti del $18^{\circ}$ Convegno Internazionale di Studi, Centro di Studi di Storia e d'Arte di Pistoia (18-21 de mayo de 2001), Pistoia, 2003, pp. 413-445; y «La población urbana en la Corona de Aragón (siglos XIV-XV)» en Las sociedades urbanas en la España medieval, XXIX Semana de Estudios Medievales de Estella (15-19 julio 2002), Pamplona 2003, pp. 151-193.

${ }^{54}$ GARCÍA DE CORTÁZAR, J. Á., «¿'Atomización'? de las investigaciones y i’regionalismo’? de las síntesis en Historia Medieval de España: ¿búsqueda de identidades o simple disminución de escala?» en La Historia Medieval hoy: percepción académica y percepción social, XXXV Semana de Estudios Medievales de Estella, Pamplona, Gobierno de Navarra, 2009, pp. 343-380.

55 Así lo he subrayado en NAVARRO ESPINACH, G., «Who is Who in Spanish Medieval Studies» en Imago Temporis. Medium Aevum, 2 (2008), pp. 45-55. 
nir por doquier grupos identitarios. De esa forma, las identidades se han entronizado como tema de reflexión a todas las escalas, con su secuela de búsqueda de raíces y propensión a la invención de la tradición que a veces ofrecen, por no hablar de los espejismos y las ilusiones que se derivan de ellas en ciertas ocasiones ${ }^{56}$.

En mi caso no es la primera vez que me acerco de alguna manera a este tema de las identidades. En noviembre de 2004 ya tuve oportunidad de tratar la interacción entre cultura popular e ideología burguesa al analizar las formas de vida de los artesanos y mercaderes de la Corona de Aragón en los siglos XIIIXVI con motivo de un seminario internacional de la Universidad de Alicante celebrado en La Nucia sobre Identidades y mentalidades en el Occidente europeo, siglos XI-XV. Seleccioné allí ciertos fenómenos para ir perfilando ese proceso interactivo como, por ejemplo, la lenta irrupción de la escritura y del notariado en el mundo urbano, la fuerte tendencia a promulgar ordenanzas y estatutos para regurarlo todo, la adopción del avecindamiento como derecho y expresión de ciudadanía, las estrategias de perpetuación en las estructuras de poder en busca de honor y riqueza, o el valor de la profesión para la génesis de identidades colectivas ${ }^{57}$.

Entonces como ahora, al volver a tratar estas cuestiones, más que constatar identidades y coherencias, sigo interesado por interpretar los conflictos y las contradicciones provocadas en la práctica por la formulación de tales fenómenos ideológicos, tal y como he intentado hacer con anterioridad al cuestionar el rango honorífico de las ciudades aragonesas frente a la acción institucional de las villas que eran como ciudades o de las aldeas que eran como villas. La construcción de una identidad colectiva no es inocente ni inerte, sino generadora de actos. Y la mejor manera de comprenderla es analizarla en orígen, antes de que se compliquen sus contenidos y se introduzca en la mentalidad de la gente con intensidad, generación tras generación, transformada en una tradición antigua de la que no exista memoria viva para contar cuándo empezó. Vista y sentida de forma tan «natural» que no parece lo que en el fondo es, al fin y al cabo, una costumbre en común inventada ${ }^{58}$.

${ }^{56}$ GÓMEZ GARCÍA, P. (coord.), Las ilusiones de la identidad, Valencia, 2001. Véase también MARTÍNEZ SAHUQUILLO, I., «La identidad como problema social y sociológico» en Arbor, 722 (2006), pp. 811-824.

${ }^{57}$ NAVARRO ESPINACH, G., «Los protagonistas del comercio: oficios e identidades sociales en la España bajomedieval» en El comercio en la Edad Media, XVI Semana de Estudios Medievales de Nájera-Tricio, Logroño, Instituto de Estudios Riojanos, 2006, pp. 147-187.

${ }^{58}$ Algunas reflexiones sobre el concepto de identidad en general o de identidad urbana en la Edad Media pueden encontrarse en HALL, S., DU GAY, P. (eds.), Questions of Cultural Identity, Londres, 1996; ARFUCH, L. (ed.), Identidades, sujetos y subjetividades, Buenos Aires, 2002; BOONE, M., STABEL, P. (eds.), Shapping Urban Identity in Late Medieval Europe, Bruselas, 2000. 
Cualquier estudio sobre formas de identidad colectiva en el pasado apela directamente a los idearios sociales que justifican la perpetuación de realidades institucionales, como ocurrió con el desarrollo de los municipios en la Edad Media y la cristalización de una ideología típicamente burguesa que los justificó. Es decir, a partir del siglo XIII de manera clara los burgueses crearon una cultura acorde con su función económica y política en Europa ${ }^{59}$. Algo que reivindica la prioridad de estudiar bien la economía, la estructura de clases y el poder en el mundo urbano para situar, medir y datar correctamente dicho fenómeno cultural. Las identidades urbanas en la Edad Media, allí donde sea posible documentarlas, fueron una construcción ideológica propia de la burguesía, y sólo desde el conocimiento previo de la historia económico-social e institucional de cada contexto local o regional será posible comprender su formulación, a sabiendas de que es un fenómeno de fronteras imprecisas y difusas, por lo que las dudas a resolver son muchas. ¿Qué juego de factores hizo posible su formulación? ¿Cuándo y dónde? ¿Con qué amalgama de componentes se materializó esa ideología burguesa? ¿Cuáles pesaron más en el proceso de consolidación de la misma? ¿Qué impacto tuvo ese sistema de valores en el resto del vecindario no burgués? ¿Acabó convertido en un ideario de masas? ¿Cómo interactuó con la mentalidad caballeresca y aristocrática propia del orden feudal imperante? ¿Y con la cultura popular?

En ámbito penínsular ya hay varios ensayos que abogan desde hace tiempo por la comparación de modelos de identidades urbanas ${ }^{60}$. En el reino de Aragón se han ampliado bastante los datos existentes gracias a varios estudios derivados de un proyecto de investigación del Grupo de Excelencia C.E.M.A de la Universidad de Zaragoza en torno a la prosopografía de las sociedades urbanas ${ }^{61}$.

${ }^{59}$ LE GOFF, J., Mercaderes y banqueros en la Edad Media, Madrid, Alianza Editorial, 2004 (orig. 1956).

${ }^{60}$ DEL VAL VALDIVIESO, M. I., «La identidad urbana al final de la Edad Media» en Anales de Historia Medieval de la Europa Atlántica, 1 (2006), pp. 5-28; JARA FUENTE, J. A., «Identidad corporativa y constitución política urbana: solidaridades económicas y poder en el marco de los procesos de afianzamiento de las rentas concejiles» en Fiscalidad, sociedad y poder en las ciudades castellanas de la Baja Edad Media, Universidad Autónoma de Madrid, 2006, pp. 1160; SOLÓRZANO TELECHEA, J. A., «Linaje, comunidad y poder: desarrollo y consolidación de identidades urbanas contrapuestas en la Castilla bajomedieval» en Familia y sociedad en la Edad Media (siglos XII-XV), Universidad de Zaragoza, 2007, pp. 71-93; BARRIO BARRIO, J. A., «La construcción de modelos de identidad urbana en las villas y ciudades de la Gobernación de Orihuela, ss. XIII-XV» en Canelobre, 52 (2007), pp. 241-253; y GUERRERO NAVARRETE, Y., «Identidad y 'honor' urbano: cortes en Burgos (1391-1392)» en Castilla y el mundo feudal: homenaje al profesor Julio Valdeón, Valladolid, 2009, vol. 1, pp. 551-563.

${ }^{61}$ SESMA MUÑOZ, J. A., LALIENA CORBERA, C., NAVARRO ESPINACH, G., «Prosopografía de las sociedades urbanas de Aragón durante los siglos XIV y XV. Un balance provisional» en La prosopografía como método de investigación sobre la Edad Media, Universidad de Zaragoza, 2006, pp. 7-19. 
En definitiva, si hay que proponer un listado de formas de ideología burguesa a partir del observatorio aragonés, éste debe comenzar por el concepto mismo de ciudad no sólo como rango honorífico concedido de facto por la monarquía a petición de los municipios, sino también como el techo simbólico más alto al que aspiraban a llegar el conjunto de villas y aldeas ${ }^{62}$.

Otro componente ideológico de gran interés lo constituye la condición de vecindad. Las estrategias jurisdiccionales de las autoridades municipales tendieron a elaborar una política propia de planificación del territorio concediendo cartas de ciudadanía o privilegios de residencia a los forasteros más ricos para hacer de sus ciudades el epicentro económico de cada región. Los actos de avecindamiento para acoger sobre todo a mercaderes distanciaban así al resto de inmigrantes del mismo origen y marcaban ya un doble juego de identidad/ alteridad a través de la noción de ciudadanía que legitimaba la territorialidad urbana. Cuando el peso de la soberanía de las ciudades se combinó con el de la monarquía, los criterios de alteridad se hicieron divergentes. Para las autoridades municipales la alteridad del extranjero era lo opuesto a la ciudadanía, mientras que para la monarquía denotaba lo contrario de la identidad nacional. Con el paulatino proceso de estatalización que se pone en marcha de manera clara a partir de Jaime I en el siglo XIII comenzaron a convivir y contrarrestarse ambas ideas entre las elites políticas de la Corona ${ }^{63}$.

Es en ese contexto de desarrollo institucional de las ciudades y de los estados en el que cabe interpretar fenómenos significativos como los avecindamientos y las cartas de franqueza en contraste con la inmigración invisible de la mano de obra foránea, detectable sobre todo a través de la contratación ante notario. Por ejemplo, entre los 6.248 nuevos vecinos de Valencia figuran hasta 681 aragoneses (un diez por ciento) procedentes de 140 localidades distintas, sobre todo de las tierras de la actual provincia de Teruel, cuando en paralelo, el acceso al mercado de trabajo a través de contratos de aprendizaje y servicio doméstico ante notario proporciona toda una corriente de jóvenes inmigrantes que queda por supuesto al margen de los registros de avecindamiento. Casi tres de cada diez jóvenes contratados ante notario en la capital valenciana venían de fuera del reino y de ellos hasta un sesenta por ciento procedían de Aragón y eran en gran parte hijos de campesinos. Este sistema de inserción se postula pues como una

${ }^{62}$ Uno de los pocos artículos dedicados a este tema fuera del reino de Aragón es el de DEL ESTAL GUTIÉRREZ, J. M., «Conversión de la villa de Alicante en ciudad» en Anales de la Universidad de Alicante. Historia Medieval, 7 (1988-1989), pp. 225-242.

${ }^{63}$ NAVARRO ESPINACH, G., «La presencia de grupos extranjeros en la Corona de Aragón (siglos XIII-XV)» en La Corona de Aragón en el centro de su historia. 1208-1458. Aspectos económicos y sociales, Zaragoza, 2010, pp. 161-190. 
especie de agencia alternativa de socialización y aculturación para la mayoría ilegal de inmigrantes ${ }^{64}$.

En contraste, en la ciudad de Zaragoza como en el resto de concejos aragoneses no se han conservado libros de avecindamientos ni se han estudiado de forma sistemática las cartas de franqueza para nuevos vecinos que aparecen insertas de forma irregular a lo largo de los libros de actas de los diversos municipios. El propio mercado local de la mano de obra en Zaragoza apunta también a un tipo de inmigración velada de grupos extranjeros poco visibles en la documentación municipal. De hecho, las autoridades zaragozanas crearon en 1442 el cargo de corredor de firmar mozos para controlar en la medida de lo posible la afluencia de huérfanos y jóvenes foráneos en busca de trabajo ${ }^{65}$. En ese sentido, una cata realizada en los libros notariales de la Zaragoza del siglo XV sobre 322 contratos de aprendizaje permite afirmar que al menos un cuarenta por ciento de los jóvenes inmigrantes en la capital eran extranjeros del reino, sobre todo castellanos, navarros y del sur de Francia ${ }^{66}$. Poco o nada tenían que ver con quienes obtenían del municipio un privilegio de residencia o carta de franqueza que expresaba antes que nada la identidad burguesa del colectivo de cabezas de familia con residencia estable que pagaba regularmente los impuestos locales. Al respecto, en los libros de la pecha de las villas de la bailía de Cantavieja se tenía por costumbre disminuir dos fuegos por cada decena de las cifras de los fogajes reales en virtud del cómputo de personas miserables o extrañas que solía haber y que eran llamadas así porque no podían pagar o no estaban obligadas a hacerlo al no tener la vecindad ${ }^{67}$.

Está por hacer todavía un mapa de los términos municipales aragoneses de la Edad Media que permita reconocer con mayor o menor precisión el espacio social considerado como propio por cada comunidad local. En el caso de Zaragoza ya se cuenta con un primer ensayo de aproximación ${ }^{68}$ pero la cuestión de fondo que hay que resolver no es simplemente topográfica. Establecer los límites físicos del territorio sobre el cual ejercía su jurisdicción un concejo es estudiar la

${ }^{64}$ Los datos proceden de NAVARRO ESPINACH, G., «Política municipal y avecindamientos. Análisis de la emigración aragonesa a Valencia (1308-1526)» en Demografía y sociedad en la España bajomedieval, Zaragoza, 2002, pp. 97-128.

${ }^{65}$ SAN VICENTE PINO, Á., El oficio de padre de huérfanos en Zaragoza, Universidad de Zaragoza, 1965.

${ }^{66}$ FALCÓN PÉREZ, M. I., «Fuentes para la historia del trabajo en la Baja Edad Media aragonesa» en Actas de las Jornadas sobre Metodología de la Investigación Científica sobre Fuentes Aragonesas (Monzón, 1985), Zaragoza, 1986, pp. 165-177.

${ }^{67}$ NAVARRO, G., VILLANUEVA, C., Libro de la bailía de Cantavieja..., citado, p. 21.

${ }^{68}$ FALCÓN PÉREZ, M. I., Zaragoza en el siglo XV. Morfología urbana, huertas y término municipal, citado. 
formación y evolución de un señorío urbano: propiedades, rentas, uso de bienes colectivos, administración del patrimonio municipal, etc. La expresión simbólica por excelencia de ese poder era precisamente la muralla de la población. De hecho, la primera condición física que había de cumplir cualquier espacio urbano para considerarse como tal era estar amurallado. La esencia de la vida urbana se desarrollaba dentro del recinto o ante sus puertas. La ideología burguesa construyó así espacios comunitarios de convivencia que apelaban a sentimientos de colectividad en unas y otras localidades: calles, plazas, casas del concejo, parroquias, cuartones, catedrales, hospitales, casas de cofradías o estudios entre otros más ${ }^{69}$. Es cierto que se ha insistido en la estructura arquitectónica del mundo urbano aragonés ${ }^{70}$ pero no se ha valorado todavía por ejemplo un aspecto tan importante como es la génesis del esquema parroquial de cada lugar, lo que nos traslada a la noche de los tiempos cuando muchos concejos no habían nacido todavía ${ }^{71}$.

En contraste, los estudios sobre demografía urbana aragonesa están a la vanguardia de la historiografía penínsular ${ }^{72}$ y la historia de la economía y de los mercados en el reino, aunque sea una tendencia «retro» en la actualidad, ha iniciado un fructífero itinerario de resultados ${ }^{73}$. Pero aún así, la conciencia del territorio propio, del espacio social urbano y de su compartimentación interior, es sin duda otro componente ideológico de primera magnitud que está en stand-by a la espera de su historiador/a en Aragón. Ha pesado más el análisis institucional de los concejos en sus diversas modalidades ${ }^{74}$ con alusión a sus fuentes documentales típicas, la tipología de cargos y sus capacidades judicial, ejecutiva, normativa o fiscal, por no hablar de otros múltiples aspectos derivados de la acción de gobierno: obras públicas, fiestas civiles y religiosas, avituallamientos y tasas de precios, salubridad e higiene, mantenimiento de la paz urbana, prostitución

${ }^{69}$ IRANZO MUÑíO, M. T., «Ciudad, ideología urbana y poder político en Huesca (siglos XIIXIV)» en XVII Congrés d'Història de la Corona d'Aragó, Barcelona, 2003, vol. 3, pp. 421-436.

${ }^{70}$ BETRÁN ABADÍA, R., La forma de la ciudad. Las ciudades de Aragón en la Edad Media, Zaragoza, Colegio de Arquitectos de Aragón, 1992.

${ }^{71}$ Sería deseable para Aragón un estudio como el de GUINOT, E., Els límits del regne. El procés de formació territorial del País Valencià medieval (1238-1500), Valencia, 1995, donde por cierto se alude a la evolución de la frontera valenciana con Aragón en la Edad Media o más concretamente en el siglo XIII al conflicto de términos con la comunidad de aldeas de Teruel.

${ }^{72}$ SESMA MUÑOZ, J. Á., LALIENA CORBERA, C. (coords.), La población de Aragón en la Edad Media (siglos XIII-XV). Estudios de demografía histórica, Zaragoza, 2004.

${ }^{73}$ SESMA MUÑOZ, J. Á., LALIENA CORBERA, C. (coords.), Crecimiento económico y formación de los mercados en Aragón en la Edad Media (1200-1350), Zaragoza, 2009.

${ }^{74}$ FALCÓN PÉREZ, M. I., «Origen y desarrollo del municipio medieval en el reino de Aragón» en Estudis Baleàrics, vol. V, núm. 31 (1989), pp. 73-92. 
y juegos, aprovechamiento de fuentes de riqueza de los términos, actividades artesanales y comerciales o cartas de vecindad y leyes suntuarias entre otros asuntos más ${ }^{75}$.

Por otro lado, un elemento de análisis muy importante para evaluar la construcción de la identidad de las ciudades y villas aragonesas se esconde en el ámbito de las relaciones con la monarquía. Me refiero por ejemplo al contraste existente entre la imagen que cada municipio tenía de sí mismo y la que le atribuían la monarquía o el resto de universidades del brazo o estamento de las cortes del reino. En ese sentido, al margen de conocer bien y con detalle la cronología general con la que la corona intervino en el gobierno en los concejos aragoneses a través de la insaculación de $\operatorname{cargos}^{76}$, se ha abordado también la jerarquía prelatoria de las diferentes ciudades, villas y comunidades de aldeas representadas en el brazo o estamento de las universidades durante las cortes aragonesas de los reinados de Alfonso V y Juan $\mathrm{II}^{77}$. ¿Quiénes decidían el orden jerárquico con el que se sentaban en el parlamento? ¿Por qué de forma repetitiva se situaban siempre en cabeza Zaragoza y Huesca? ¿Fue así durante el siglo XIV? ¿Lo consensuaba el propio estamento o venía impuesto por el rey?

Desde luego, la posición de cercanía al rey era el referente a tener en cuenta. A finales del siglo XV, en los bancos que estaban a lo largo de la mano derecha del rey se ponía el brazo eclesiástico y a la mano izquierda los nobles, y más a la izquierda de éstos los caballeros y escuderos. Por último, en los bancos traveseros que estaban cara a cara frente al rey se sentaban las universidades. En la primera fila a la parte derecha del rey se ponían los procuradores de Huesca, en medio los de Zaragoza, a la izquierda los de Tarazona y detrás por orden estricto estaban todos los demás. Un claro componente simbólico de reconocimiento y prestigio externos para las identidades urbanas de Aragón sobre el que habrá que volver a profundizar más y más ${ }^{78}$.

${ }^{75}$ FALCÓN PÉREZ, M. I., «Gobierno y poder municipal en las ciudades de Aragón en la Baja Edad Media» en XVII Congrés d'Història de la Corona d'Aragó, Barcelona, 2003, vol. 1, pp. 59-99.

${ }^{76}$ FALCÓN PÉREZ, M. I., «La introducción del sistema insaculatorio para la provisión de cargos municipales en Aragón» en XVI Congresso Internazionale di Storia della Corona d'Aragona, Nápoles, 2000, vol. 1, pp. 253-276.

77 SÁNCHEZ ARAGONÉS, M. L., Cortes, monarquía y ciudades en Aragón durante el reinado de Alfonso el Magnánimo (1416-1458), Zaragoza, Institución Fernando el Católico, 1994. Véase también de la misma autora, Las Cortes de la Corona de Aragón durante el reinado de Juan II (1458-1479): monarquía, ciudades y relaciones entre el poder y los súbditos, Zaragoza, Institución Fernando el Católico, 2004.

${ }^{78}$ BLANCAS, J., Modos de proceder en las Cortes de Aragón, Zaragoza, 1641; y MARTEL, J., Formas de celebrar Cortes en Aragón, Zaragoza, 1841. 
También ha sido muy poco estudiado el tema de la fiscalidad municipal en Aragón ${ }^{79}$, hasta el punto que las dificultades para elaborar un glosario fiscal del reino resultan considerables como he podido comprobar durante la realización del proyecto Les mots de l'impôt dans l'Occident Méditerranéen. Base de données critique de fiscalité médiévale, dirigido por Manuel Sánchez y Denis Menjot y patrocinado por el Comité pour l'Histoire Économique et Financière de la France. Sin duda, la fiscalidad constituyó un componente fundamental de las identidades urbanas en todas partes (pechas, sisas, herbajes...). El concepto mismo de vecino o ciudadano reposaba sobre la responsabilidad fiscal de quienes ostentaban tal condición reconocida por los municipios. Ahora bien, mientras no se promuevan investigaciones sistemáticas y más pormenorizadas en este ámbito, al menos en Aragón las dificultades de avance serán considerables. La historiografía de un futuro inmediato debe acometer tal reto.

Otro aspecto de estudio de enorme interés es la difusión de modelos ideológicos nobiliarios entre mercaderes, juristas y terratenientes de las elites urbanas que disfrutaban de fortunas suficientes como para comprar señoríos, caballerías y armas, emparentar con linajes aristocráticos o formar sus propios bandos o redes clientelares. Todo un espacio de intersección social en el que circulaban miembros de la burguesía hacia la nobleza urbana y a la inversa con la gestación de fuertes nexos patrimoniales de generación en generación. El patriciado urbano se dotó así de una apariencia aristocrática sobre todo en el siglo XV, en pleno proceso de oligarquización de los municipios. En el terreno ideológico, conceptos fundamentales de la ética aristocrática como el honor empezaron a difundirse con éxito entre los burgueses, como si se tratase de otro capital más que acumular, meramente simbólico pero muy útil para realzar lo propio y menoscabar lo ajeno ${ }^{80}$. Temática que responde ya de hecho a esa pregunta antes planteada sobre cómo interactuó la ideología burguesa con la mentalidad caballeresca y aristocrática propia del orden feudal imperante.

Por último, la imbricación entre ideología burguesa y cultura popular puede estudiarse mejor a partir del tema de las fiestas y rituales públicos. De hecho, la celebración de las exequias fúnebres de los monarcas tenía grandes similitudes con los actos que festejaban la imagen de cualquier otro santo de la devoción popular en un intento de acercar la monarquía a la población ciudadana por parte

${ }^{79}$ FALCÓN PÉREZ, M. I., «Finanzas y fiscalidad de ciudades, villas y comunidades de aldeas aragonesas» en Finanzas y fiscalidad municipal, Actas del V Congreso de Estudios Medievales de la Fundación Sánchez Albornoz, León, 1997, pp. 239-273.

${ }^{80}$ LALIENA CORBERA, C., IRANZO MUÑíO, M. T., «Poder, honor y linaje en las estrategias de la nobleza urbana aragonesa (siglos XIV-XV)» en Revista d'Història Medieval, 9 (1998), pp. 41-80. 
de las autoridades municipales a la vez que se pretendía reforzar la identidad local, por inconsciente que de ello pudiera ser el vecindario ${ }^{81}$. Algo que es nítido en ejemplos de ciudades que buscaron con la exaltación del Corpus Christi un factor más de distinción y relevancia frente al resto: Non fecit taliter omni nationi presume el escudo de Daroca ${ }^{82}$.

\section{APÉNDICE. \\ NÓMINA DE CIUDADES Y VILLAS DEL REINO DE ARAGÓN EN EL SIGLO XV}

Tras el nombre de cada lugar se indica de forma abreviada la provincia en la que se localiza actualmente ( $\mathrm{H}$ - Huesca, $\mathrm{T}$ - Teruel y Z - Zaragoza). Después figura una cifra que corresponde al número de fuegos registrado en el fogaje de 1495. Los asteriscos (*) indican que dicha cifra contiene la suma de la población y sus aldeas. A continuación se anota el calificativo de ciudad o villa con el que aparece en las fuentes, haciendo constar en su caso el año en que se le otorgó el título de ciudad. Se anotan asimismo los privilegios de mercado y feria con los años de concesión, su asiento en cortes en el brazo o estamento de las universidades del reino, si fueron centros episcopales o administrativos del reino (merinados, sobrejunterías y sobrecollidas), o bien cabezas de encomiendas de órdenes militares y de comunidades de aldeas, e incluso lugares de reunión de los parlamentos del reino o de la corona.

\begin{tabular}{|l|}
\hline Adahuesca (H) 46: villa de señorío. \\
\hline Aguarón (Z) 60: villa de señorío del monasterio de Trasobares. \\
\hline Aguaviva (T) 44: villa de señorío de la orden del Hospital. \\
\hline Aguilón (Z) 84: villa de realengo de la comunidad de aldeas de Daroca. \\
\hline Aínsa (H) 106: villa de realengo, feria (1296), merinado, sobrecollida, asiento en cortes. \\
\hline Aisa (H) 26: villa de realengo. \\
\hline Ainzón (Z) 66: villa de señorío del monasterio de Veruela. \\
\hline Alagón (Z) 144: villa de realengo, lugartenencia de sobrejuntería, asiento en cortes. \\
\hline Albalate del Arzobispo (T) 238: villa de señorío del arzobispo de Zaragoza. \\
\hline $\begin{array}{l}\text { Albarracín (T) 99: ciudad de realengo (1300) con comunidad de aldeas (1284), sede episcopal } \\
\text { (1172), feria (1297), mercado (1351), asiento en cortes. }\end{array}$ \\
\hline
\end{tabular}

${ }^{81}$ LALIENA CORBERA, C., IRANZO MUÑ́O, M. T., «Las exequias de Alfonso V en las ciudades aragonesas. Ideología real y rituales públicos» en Aragón en la Edad Media, IX (1991), pp. 55-75.

${ }^{82}$ CORRAL LAFUENTE, J. L., «Una Jerusalén en el Occidente medieval: la ciudad de Daroca y el milagro de los Corporales» en Aragón en la Edad Media, XII (1995), pp. 61-122. 


\begin{tabular}{|c|c|}
\hline \multicolumn{2}{|l|}{ Alcalá (T) 88: villa de señorío. } \\
\hline $\begin{array}{l}\text { Alcañiz (T) 702: ciudad de señorío con aldeas y encomienda } \\
\text { sobrecollida, lugartenencia de sobrejuntería, asiento en cortes } \\
(1371-1372,1411 \text { y 1436). }\end{array}$ & $\begin{array}{l}\text { la orden de Calatrava, feria (1284), } \\
\text { reuniones del parlamento aragonés }\end{array}$ \\
\hline \multicolumn{2}{|l|}{ Alcolea de Cinca (H) 114: villa de señorío. } \\
\hline \multicolumn{2}{|l|}{ Alcorisa (T) 176: villa de señorío de la orden de Calatrava. } \\
\hline \multicolumn{2}{|l|}{ Alfajarín (Z) 55: villa de señorío. } \\
\hline \multicolumn{2}{|l|}{ Alfambra (T) 57: villa de señorío de la orden del Hospital. } \\
\hline \multicolumn{2}{|c|}{ Aliaga (T) 67: villa de señorío y encomienda de la orden del Hospital, mercado (1196). } \\
\hline \multicolumn{2}{|l|}{ Almolda, La (H) 96: villa de señorío. } \\
\hline \multicolumn{2}{|l|}{ Almonacid de la Sierra (Z) 88: villa de señorío. } \\
\hline \multicolumn{2}{|l|}{ Almudévar $(\mathrm{H}) 113^{*}$ : villa de realengo con aldeas, asiento en cortes. } \\
\hline \multicolumn{2}{|l|}{ Almunia, La (Z) 185: villa de señorío de la orden del Hospital. } \\
\hline \multicolumn{2}{|c|}{ Alquézar (H) 65*: villa de realengo con aldeas, mercado (1114), asiento en cortes. } \\
\hline \multicolumn{2}{|c|}{ Ambel (Z) 106: villa de señorío de la orden del Hospital. } \\
\hline \multicolumn{2}{|l|}{ Andorra (T) 136: villa de señorío del arzobispo de Zaragoza. } \\
\hline \multicolumn{2}{|l|}{ Ansó (H) 82: villa de realengo. } \\
\hline \multicolumn{2}{|l|}{ Araguás (H) 19: villa de señorío del monasterio de San Victorián. } \\
\hline \multicolumn{2}{|l|}{ Aranda (Z) 207: villa de señorío. } \\
\hline \multicolumn{2}{|l|}{ Arándiga (Z) 32: villa de señorío. } \\
\hline \multicolumn{2}{|l|}{ Arens de Lledó (T) 35: villa de señorío del cabildo de Tortosa. } \\
\hline \multicolumn{2}{|l|}{ Ariza (Z) 135: villa de señorío. } \\
\hline \multicolumn{2}{|l|}{ Ayerbe $(\mathrm{H})$ 89: villa de señorío. } \\
\hline \multicolumn{2}{|c|}{$\begin{array}{l}\text { Barbastro (H) 455: ciudad de realengo (1100), merinado, sobrecollida, lugartenencia de } \\
\text { sobrejuntería, asiento en cortes. }\end{array}$} \\
\hline \multicolumn{2}{|l|}{ Beceite (T) 108: villa de señorío del arzobispo de Zaragoza. } \\
\hline \multicolumn{2}{|l|}{ Belchite (Z) 245: villa de señorío. } \\
\hline \multicolumn{2}{|l|}{ Belmonte (T) 47: villa de señorío de la orden de Calatrava. } \\
\hline \multicolumn{2}{|l|}{ Benabarre $(\mathrm{H})$ 90: villa de realengo. } \\
\hline \multicolumn{2}{|l|}{ Benasque (H) 55: villa de realengo. } \\
\hline \multicolumn{2}{|l|}{ Berbegal (H) 70: villa de realengo. } \\
\hline \multicolumn{2}{|l|}{ Biel (Z) 113: villa de señorío del arzobispo de Zaragoza. } \\
\hline \multicolumn{2}{|l|}{ Bielsa (H) 80: villa de realengo. } \\
\hline \multicolumn{2}{|l|}{ Bolea $(\mathrm{H})$ 100: villa de realengo. } \\
\hline \multicolumn{2}{|l|}{ Boltaña $(\mathrm{H}) 70$ : villa de realengo. } \\
\hline Bordón (T) 28: villa de señorío de la orden del Hospital. & \\
\hline Borja (Z) 469: ciudad de realengo (1438), asiento en cortes. & \\
\hline
\end{tabular}


Brea (Z) 30: villa de señorío del cabildo del Pilar de Zaragoza.

Broto (H) 51: villa de realengo, lugartenencia de sobrejuntería.

Bujaraloz (H) 55: villa de señorío del monasterio de Sigena.

Calaceite (T) 114: villa de señorío del cabildo de Tortosa.

Calanda (T) 119: villa de señorío de la orden de Calatrava.

Calatayud (Z) 1.027: ciudad de realengo (1366) con comunidad de aldeas (1254), feria (1276), merinado, sobrecollida, asiento en cortes, reuniones del parlamento aragonés (1365-1366, 1411, 1461 y 1515).

Calatorao (Z) 68: villa del cabildo del Pilar de Zaragoza.

Calcena (Z) 114: villa de señorío del obispo de Tarazona.

Calmarza (Z) 33: villa de señorío.

Campillo (Z) 37: villa de señorío de la orden del Hospital.

Canfranc (H) 74: villa de realengo.

Cantavieja (T) 126: villa de señorío y encomienda de la orden del Hospital, mercado (1225).

Cañada, La (T) 53: villa de señorío de la orden del Hospital.

Capella (H) 53: villa de señorío.

Carenas (Z) 91: villa de señorío del monasterio de Piedra.

Cariñena (Z) 347: villa de realengo de la comunidad de aldeas de Daroca, reunión del parlamento aragonés (1357).

Cascante (T) 40: villa de señorío.

Caspe (Z) 295: villa de señorío y encomienda de la orden del Hospital, reunión del parlamento aragonés (1371-1372).

Castellote (T) 164*: villa de señorío con sus masadas y encomienda de la orden del Hospital, mercado (1268).

Castelserás (T) 44: villa de señorío de la orden de Calatrava.

Cetina (Z) 186: villa de señorío.

Chiprana (Z) 24: villa de señorío de la orden del Hospital.

Cretas (T) 91: villa de señorío de la orden de Calatrava.

Cuba, La (T) 19: villa de señorío de la orden del Hospital.

Cuervo, El (T) 27: villa de señorío.

Cuevas de Cañart, Las (T) 116: villa de señorío de la orden del Hospital.

Cutanda (T) 71: villa de realengo.

Daroca (Z) 437: ciudad de realengo (1366) con comunidad de aldeas (1248), feria (1294), merinado, asiento en cortes.

Ejea (Z) 411: villa de realengo, merinado, sobrejuntería, asiento en cortes.

Ejulve (T) 124: villa de señorío de la orden de Calatrava.

Encinacorba (Z) 162: villa de señorío de la orden del Hospital. 


\begin{tabular}{|c|}
\hline Épila (Z) 161: villa de señorío, merinado. \\
\hline Escatrón (Z) 88: villa de señorío del monasterio de Rueda. \\
\hline Estercuel (T) 79: villa de señorío. \\
\hline Fabara (Z) 129: villa de señorío. \\
\hline Fantova $(\mathrm{H}) 21$ : villa de realengo. \\
\hline Fornoles (T) 41: villa de señorío de la orden de Calatrava. \\
\hline Fortanete (T) 89: villa de señorío de la orden del Hospital. \\
\hline Fonz (H) 82: villa de señorío del obispo de Lérida. \\
\hline Foz-Calanda (T) 35: villa de señorío de la orden de Calatrava. \\
\hline $\begin{array}{l}\text { Fraga }(\mathrm{H}) 307 \text { : villa de realengo con aldeas, asiento en cortes, reuniones del parlamento aragonés } \\
(1383-1384 \text { y } 1460) \text {. }\end{array}$ \\
\hline Fresneda, La (T) 180: villa de señorío de la orden de Calatrava. \\
\hline Fuentes (Z) 197: villa de señorío. \\
\hline Fuentespalda (TE) 60: villa de señorío del arzobispo de Zaragoza. \\
\hline Gea (T) 101: villa de señorío. \\
\hline Gelsa (Z) 90: villa de señorío. \\
\hline Ginebrosa, La (T) 58: villa de señorío de la orden del Hospital. \\
\hline Godojos (Z) 22: villa de señorío. \\
\hline $\begin{array}{l}\text { Graus (H) 143: villa de señorío del monasterio de San Victorián, mercado (1073, } 1272 \text { y 1322), } \\
\text { feria (1201, 1316 y 1322). }\end{array}$ \\
\hline Hecho (H) 96: villa de realengo. \\
\hline Híjar (T) 211: villa de señorío, mercado (1271), feria (1280). \\
\hline Huesa (T) 244: villa de realengo de la comunidad de aldeas de Daroca, mercado (1320). \\
\hline $\begin{array}{l}\text { Huesca (H) 616: ciudad de realengo y sede episcopal (1100), merinado, lugartenencia de } \\
\text { sobrejuntería, asiento en cortes, reunión del parlamento aragonés (1247). }\end{array}$ \\
\hline Ibdes (Z) 180: villa de realengo de la comunidad de aldeas de Calatayud. \\
\hline Iglesuela, La (T) 69: villa de señorío de la orden del Hospital. \\
\hline Illueca (Z) 57: villa de señorío. \\
\hline $\begin{array}{l}\text { Jaca (H) 143: ciudad de realengo (1077), feria (1187), mercado (1197), merinado, lugartenencia } \\
\text { de sobrejuntería, asiento en cortes. }\end{array}$ \\
\hline Jarque (Z) 51: villa de señorío. \\
\hline Lanaja $(\mathrm{H})$ 122: villa de señorío del monasterio de Sigena. \\
\hline Lascuarre (H) 44: villa de señorío. \\
\hline Lécera $(Z)$ 85: villa de señorío. \\
\hline Linares (T) 55: villa de señorío del arzobispo de Zaragoza, feria (1406), mercado (1407). \\
\hline Longares (Z) 117: villa de realengo. \\
\hline Luco (T) 32: villa de señorío de la orden del Hospital. \\
\hline
\end{tabular}




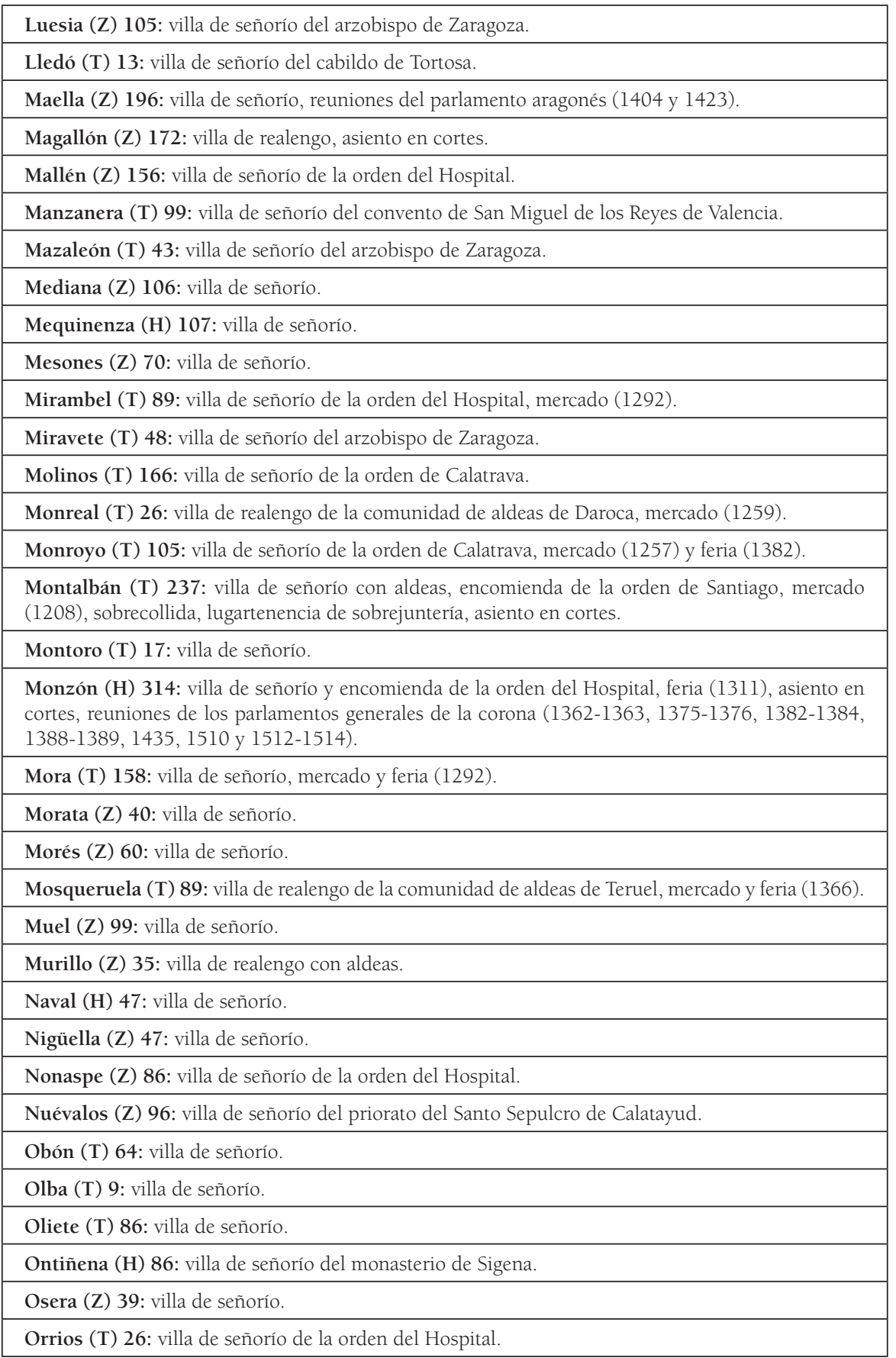




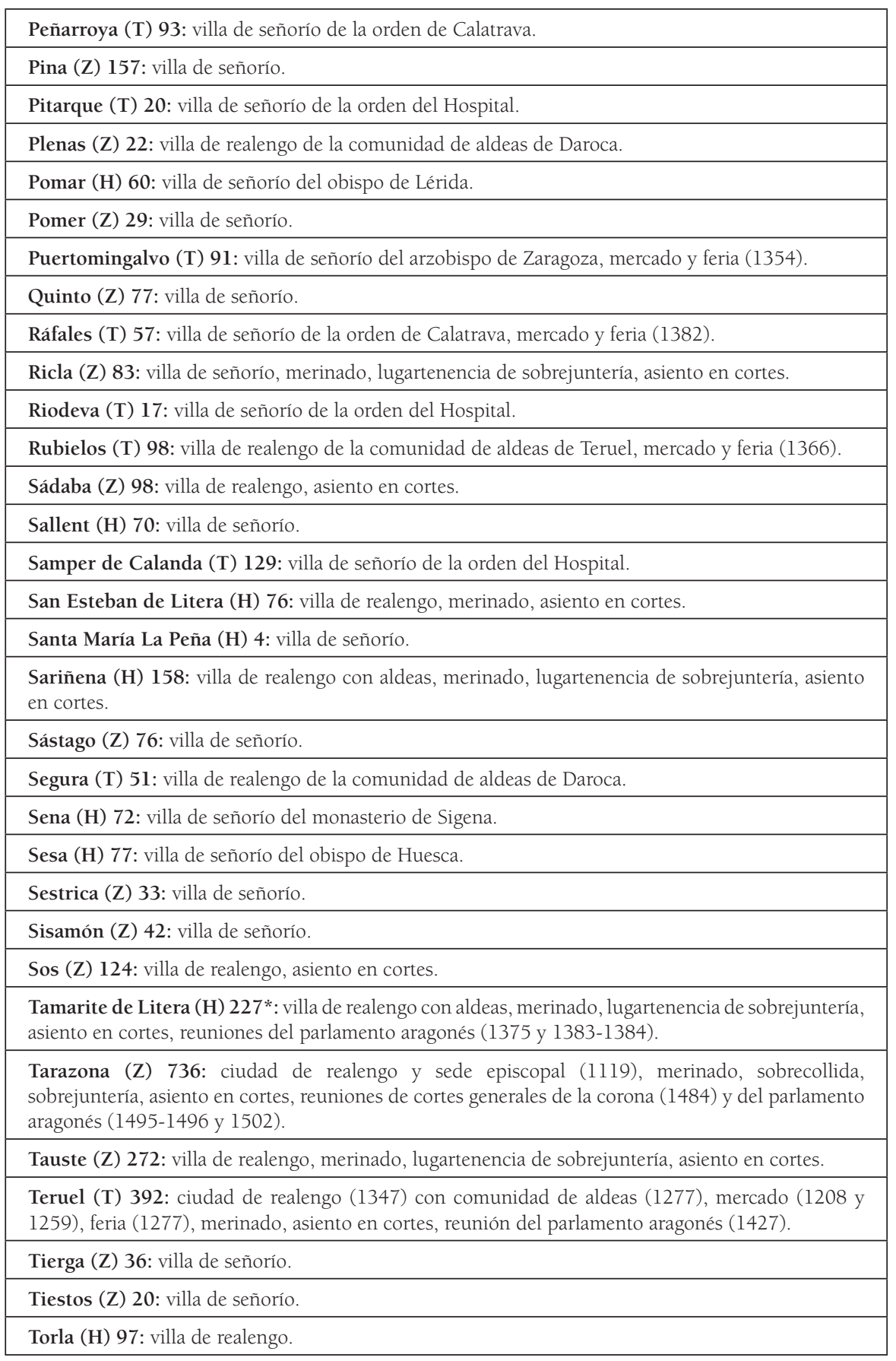




\begin{tabular}{|c|}
\hline Tormón (T) 34: villa de señorío. \\
\hline Torralba de los Frailes (Z) 57: villa de señorío del priorato del Santo Sepulcro de Calatayud. \\
\hline Torre del Compte (T) 49: villa de señorío del arzobispo de Zaragoza. \\
\hline Torrehermosa (Z) 45: villa de realengo. \\
\hline Tramacastiel (T) 34: villa de señorío. \\
\hline Trasobares (Z) 76: villa de señorío del monasterio de Trasobares. \\
\hline Tronchón (T) 91: villa de señorío de la orden del Hospital. \\
\hline Uncastillo (Z) 156: villa de realengo, lugartenencia de sobrejuntería, asiento en cortes. \\
\hline Urdués (H) 45: villa de realengo. \\
\hline Urrea (Z) 50: villa de señorío. \\
\hline Valacloche $(\mathrm{T})$ 15: villa de señorío. \\
\hline Valbona (T) 60: villa de señorío. \\
\hline $\begin{array}{l}\text { Valderrobres (T) 135: villa de señorío del arzobispo de Zaragoza, feria (1308), reunión del } \\
\text { parlamento aragonés (1429). }\end{array}$ \\
\hline Valtorres (Z) 35: villa de señorío. \\
\hline Velilla (Z) 28: villa de señorío. \\
\hline Vera (Z) 39: villa de señorío del monasterio de Veruela. \\
\hline Villafeliche (Z) 261: villa de señorío. \\
\hline Villaluenga (Z) 88: villa de señorío de la orden del Hospital. \\
\hline Villanueva del Huerva (Z) 84: villa de realengo. \\
\hline Villarluengo (T) 83: villa de señorío de la orden del Hospital. \\
\hline Villarroya (T) 101: villa de señorío de la orden del Hospital. \\
\hline Villarroya (Z) 278: villa de realengo de la comunidad de aldeas de Calatayud. \\
\hline Villastar (T) 10: villa de señorío de la orden del Hospital. \\
\hline Villel (T) 97: villa de señorío y encomienda de la orden del Hospital. \\
\hline Vilueña, La (Z) 59: villa de señorío. \\
\hline $\begin{array}{l}\text { Zaragoza (Z) 3.983: ciudad del realengo y sede episcopal (1118), feria (1250), sede archiepiscopal } \\
\text { (1318), merinado, sobrecollida, sobrejuntería, asiento en cortes, reuniones del parlamento aragonés } \\
(1365-1367,1371-1372,1381,1398-1400,1412,1413-1414,1439,1441,1442,1446-1450 \text {, } \\
1451,1467,1493-1494 \text { y 1498). }\end{array}$ \\
\hline Zuera (Z) 151: villa de realengo, mercado (1258), merinado. \\
\hline
\end{tabular}

